\title{
PERFORMANCE OF SOME PROMISING EGYPTIAN RICE GENOTYPES UNDER DIFFRENET LOCATIONS
}

\author{
Elgohary A.A., I.M. Hashem, T.F. Metwally and S.E.M. \\ Sedeek \\ Rice Research Dpartment, Field Crops Research Institute, \\ Agricultural Research Center, 33717 Sakha - Kafr El-Sheikh, \\ Egypt.
}

\begin{abstract}
Multilocation and on stations trials were conducted during 2013 and 2014 to evaluate the performance of twelve rice genotypes under three locations; Sakha (Kafer El-Sheikh Governorate), Gemmiza (El-Gharbia Governorate) and Zarzoura (El-Behira Governorate). The experiments were conducted using Randomized Complete Block Design with four replications. Combined analysis of variance among the different locations was done.

The results obtained showed highly significant differences among rice genotypes, locations, and genotypes by locations interaction. The rice genotypes recorded the highest values of grain yield at Gemmiza location, surpassing significantly the other two locations. These results indicate that the studied genotypes responded differently to the different environmental conditions suggesting the importance of evaluation of genotypes under different environments in order to identify the best genetic make up for a particular environment. The rice genotypes GZ9523-2-1-1-1, Giza 179 and Sakha 101 recorded the highest values of grain yield under the three locations, of Sakha, Gemmiza and Zarzoura during 2013 and 2014 seasons compared with the other genotypes, indicating that those genotypes have a good adaptation under different environments conditions.

Concerning the grain quality characters among the three locations, all characters were not affected significantly in both seasons, but the differences among genotypes were significant. Stem borer infestation was affect by location and genotype while, rice blast infection differed significantly among rice genotypes. The highest values of infection of rice genotypes to stem borer were observed at Gemmiza location compared with the other two locations. Sakha101 was resistance to stem borer while, Giza177, Sakha105, Giza179, GZ9461-4-2-3-1, GZ9577-4-1-1, GZ9626-2-1-1 and GZ9807-6-3-2-1 were moderate resistance. On the other hand, Sakha106, GZ7576-10-3-2-1 and GZ9523-2-1-1-1 were moderate susceptible. However, Giza178 was susceptible to stem borer. Most of rice genotypes under study were resistant to rice blast, except Sakha 101 cultivar, which was highly susceptible under different locations in the two seasons.
\end{abstract}

Key words: Rice, adaptability, Rice genotypes $x$ locations, years interaction 


\section{INTRODUCTION}

Identification of rice genotypes with wider adaptability is the important aspects in varietal improvement and regeistrables to achieve better economic values and return to the farmers.

Information on genotype $x$ environment interaction leads to successful evaluation of stable genotype, which could be used for general cultivation. Yield is a complex quantitative character and is greatly influenced by environmental fluctuations; hence, the selection for superior genotypes based on yield at a single location in a year may not be very effective (Shrestha et al., 2012). Thus, evaluation of genotypes for adaptability of performance under varying environmental conditions for yield has become an essential part of any breeding program. Tariku et al. (2013) evaluated sixteen rainfed lowland rice genotypes at three locations of eight environments. They found that the largest proportion of the total variation in grain yields was attributed to environments in this trial. As a result, almost all of the evaluated genotypes were affected by the genotype $x$ environment interaction effects, so that no genotype had superior performance in all environments. Most of the genotypes showed environment specificity. So that it would be possible to cluster the testing locations into homogenous groups to be used for breeding for specific adaptation and/or for broad adaptation. Anputhas et al. (2011) reported that identification of rice varieties with wider adaptability and stability are the important aspects in varietal recommendation to achieve better economic benefits for farmers. Metwally et al. (2014) studied the genetic variability and performance of some Egyptian promising rice genotypes as affected by nitrogen fertilizer under two locations. They found that the studied genotypes differed significantly under different environments conditions.

This research aims to provide a reference towards understanding the adaptability of some rice genotypes at different locations. It also intends to provide information on the behavior of these genotypes under different environments.

\section{MATERIALS AND METHODS}

Twelve rice genotypes (Table 1) were evaluated during 2013 and 2014 growing seasons at three locations; Sakha, Gemmiza and Zarzoura. Randomized Complete Block Design (RCBD) with four replications was used. Each plot had ten rows of $5 \mathrm{~m}$ length and spaced $0.2 \mathrm{~m}$ apart. A combined analysis was used among the three locations in each season. 
The seed rate of $96 \mathrm{~kg}$ seed ha-1 was used. Clean seeds with at least $90 \%$ germination were soaked in water for 24 hours and incubated for 48 hours. Pre-germinated seeds were sown on $6^{\text {th }}$ and $13^{\text {th }}$ May in the first and second season respectively. Seedling at 30 days old (2-3 seedling hill $\left.{ }^{-1}\right)$ were transplanted at $20 \times 20 \mathrm{~cm}$ distance between hills and rows. The plot size measured $4 \times 3 \mathrm{~m}$. The preceding crop was barley in the both seasons. The cultural practices were done as per need of the crop. Nitrogen in the form of urea $(46.5 \% \mathrm{~N})$ was added to plots according to the recommendation (165 $\mathrm{kg} \mathrm{N}$ ha $^{-1}$ ) in two splits application, i.e. two third as basal and incorporated into the soil immediately before flooding, followed by the second dose after 30 days after transplanting.

Representative soil samples were taken at the depth of $0-30$ $\mathrm{cm}$ from the soil surface. The procedure of soil analysis followed the methods of Black et al. (1965). Results of chemical analysis in both seasons are shown in (Table 2).

Table (1): Parentage and origin for rice genotypes under study

\begin{tabular}{|c|l|l|c|c|}
\hline $\begin{array}{c}\text { N } \\
\text { o. }\end{array}$ & \multicolumn{1}{|c|}{ Entry } & \multicolumn{1}{|c|}{ Parentage } & Type & Origin \\
\hline 1 & Giza177 & Giza 171/Yu mji No.1//PiNo.4 & Japonica & Egypt \\
\hline 2 & Giza178 & Giza 175/ Milyang 49 & $\begin{array}{c}\text { Indica } \\
\text { Japonica }\end{array}$ & Egypt \\
\hline 4 & Sakha101 & Giza 176/Milyang 79 & Japonica & Egypt \\
\hline 3 & Sakha105 & GZ5581/GZ4316 & Japonica & Egypt \\
\hline 5 & Sakha106 & Giza 177/ Hexi 30 & Japonica & Egypt \\
\hline 6 & GZ7576-10-3-2-1 & GZ5418/Milyang 79 & Japonica & Egypt \\
\hline 7 & Giza179 & GZ1368/GZ6296 & Indica & Egypt \\
\hline 8 & GZ9461-4-2-3-1 & Daey2 Beyo X GZ6396 & Japonica & Egypt \\
\hline 9 & GZ9523-2-1-1-1 & GZ6522 X Zhang Jia129 & Japonica & Egypt \\
\hline 10 & GZ9577-4-1-1 & GZ6910 X Yun Lang14 & Japonica & Egypt \\
\hline 11 & GZ9626-2-1-1 & GZ7185/Non Jing70272 & Japonica & Egypt \\
\hline 12 & GZ9807-6-3-2-1 & GZ7185 X Yum Ling19 & Japonica & Egypt \\
\hline
\end{tabular}

Table (2): Some physical and chemicals analysis of the soil at the experimental sites during 2013 and 2014.

\begin{tabular}{|c|c|c|c|c|c|c|}
\hline \multirow{2}{*}{ Soil Properties } & \multicolumn{2}{|c|}{ Sakha } & \multicolumn{2}{|c|}{ Gemmiza } & \multicolumn{2}{|c|}{ Zarzoura } \\
\hline & 2013 & 2014 & 2013 & 2014 & 2013 & 2014 \\
\hline Clay \% & 57.0 & 54.5 & 40.2 & 39.9 & 55.8 & 52.3 \\
\hline Silt \% & 32.0 & 35.0 & 45.8 & 46.1 & 30.6 & 33.6 \\
\hline Sand \% & 11.0 & 11.5 & 13.0 & 14.0 & 13.6 & 14.1 \\
\hline Texture & Clayey & Clayey & $\begin{array}{l}\text { Silty } \\
\text { clay }\end{array}$ & $\begin{array}{l}\text { Silty } \\
\text { clay }\end{array}$ & Clayey & Clayey \\
\hline Organic matter\% & 1.65 & 1.55 & 1.82 & 1.67 & 1.62 & 1.59 \\
\hline Available $\mathrm{P}, \mathrm{mg} \mathrm{kg}^{-1}$ & 13.00 & 12.00 & 18.00 & 17.20 & 16.02 & 14.00 \\
\hline Available $\mathrm{NH}_{4}, \mathrm{mg} \mathrm{kg}^{-1}$ & 12.5 & 12.6 & 17.0 & 18.0 & 15.6 & 16.00 \\
\hline Available $\mathrm{NO}_{3}, \mathrm{mg} \mathrm{kg}^{-1}$ & 10.0 & 11.8 & 12.0 & 11.0 & 11.5 & 12.1 \\
\hline Available $\mathrm{K}, \mathrm{mg} \mathrm{kg}^{-1}$ & 321 & 366 & 456 & 421 & 349 & 375 \\
\hline $\mathrm{pH}(1: 2.5$ soil & 8.45 & 8.20 & 7.95 & 8.00 & 8.10 & 7.92 \\
\hline
\end{tabular}




\begin{tabular}{|l|c|c|c|c|c|c|}
\hline suspension) & 3.0 & 2.1 & 2.1 & 2.0 & 2.3 & 2.8 \\
$\mathrm{EC} \mathrm{dS} \mathrm{m}^{-1}$ (soil paste) & & & & & & \\
\hline Soluble cations, meq. $\mathrm{L}^{-1}$ & & & & & & \\
$\mathrm{Ca}^{++}$ & 7.2 & 7.0 & 5.0 & 4.8 & 6.0 & 5.5 \\
$\mathrm{Mg}^{++}$ & 1.6 & 1.5 & 2.2 & 2.4 & 1.2 & 1.4 \\
$\mathrm{~K}^{+}$ & 0.5 & 0.5 & 0.8 & 1.0 & 0.8 & 1.1 \\
$\mathrm{Na}^{+}$ & 13.0 & 12.0 & 12.0 & 11.8 & 11.8 & 12.0 \\
\hline $\mathrm{Soluble}^{-1}$ & & & & & & \\
$\mathrm{CO}_{3}^{--}$ & 0.00 & 0.00 & 0.00 & 0.00 & 0.00 & 0.00 \\
$\mathrm{H} \mathrm{CO}_{3}^{--}$ & 5.3 & 5.0 & 3.8 & 3.5 & 4.8 & 5.0 \\
$\mathrm{CL}^{-}$ & 15.0 & 14.0 & 14.7 & 14.6 & 13.9 & 14.2 \\
$\mathrm{SO}_{4}^{--}$ & 2.0 & 2.0 & 1.5 & 1.9 & 1.1 & 0.9 \\
\hline
\end{tabular}

The studied characters include flag leaf area $\left(\mathrm{cm}^{2}\right)$ at heading, plant height $(\mathrm{cm})$, duration, panicle weight $(\mathrm{g})$, number of panicles per plant, panicle length $(\mathrm{cm})$, filled grains panicle ${ }^{-1}$, panicle weight $(\mathrm{g})$, 1000-grain weight $(\mathrm{g})$ and grain yield (t/ha).

Hulling percentage, milling percentage and head rice percentage, were the ratio of, respectively, brown rice to rough rice, milled rice to rough rice and head rice to milled rice on a weight basis. For each plot, the $250 \mathrm{~g}$ of rough rice was de-hulled with a standard de-husker. Brown rice was weighed and hulling percentage was determined. The $150 \mathrm{~g}$ of brown rice was milled with a milling machine. After milling, rice bran was removed with $1.7 \mathrm{~mm}$ sieve. A cleaned sample of milled rice was weighed and milling percentage was determined. From $100 \mathrm{~g}$ of cleaned milled rice, all head rice were taken and weighed, and head rice percentage was then calculated.

Stem borer damage which caused by (Chuler agamemeson Bles) was recorded as white head percentage at the maturity stage by counting the number of white head per 100 plants according to the standard evaluation system of Rice Research and Training Center (RRTC), Sakha, Egypt. Resistance $(R)=0-3 \%$, moderately resistance $(\mathrm{MR})=3-6 \%$, moderately susceptible $(\mathrm{MS})=6-9 \%$, susceptible $(\mathrm{S})=$ $9-12 \%$ and highly susceptible (HS) $=12 \%$ (Anonymous 2009 ).

The tested genotypes were evaluated for their reaction to rice blast disease which caused by pyricularia grisea (cooke) under field conditions. . The typical blast lesions were scored, according to the Standard Evaluation System using 0-9 scale (SES of IRRI 1996) as follow: $1-2=$ resistant $(R), 3=$ moderately resistant $(M R), 4-6=$ susceptible (S), 7-9= highly susceptible (HS).

Analysis of variance was done for each location (environment). Bartlett's test was used to assess homogeneity of error variances prior to combine analysis over environments. The grain yield data for twelve genotypes in three environments were subjected to combine analysis of variance according to Gomez and Gomez (1984) (using Genstat5 
version 3.2, statistical software). Significant different means were separated at $P<0.05$ by the least significant difference (LSD) test.

\section{RESULTS AND DISCUSSION}

The effect of different locations on plant height, duration, flag leaf area and number of panicles per $\mathrm{m}^{2}$ of tested rice genotypes are shown in Table 3. Data showed that plant height affected significantly by location in the two seasons of the study thus; genotypes which planted at Zarzoura recorded the tallest plants followed by those planted at Gemmiza. These variations could be attributed to the characteristics (Table 1). Plant height at harvest showed significant differences among the twelve genotypes (Table, 3). Sakha106 recorded the highest values of plant height at harvest followed by Sakha106 while, GZ9626-2-1-1 recorded the shortest plants. These differences among the rice genotypes mainly due to their differences in genetic background. Sedeek et al. (2009) and Faruq et al. (2011) found a significant genetic variation among genotypes in plant height. The interaction between location and genotype had no significant effect on plant height in the two seasons.

Regarding to plant duration, data in Table (3) showed that planting rice at different location didn't affect the duration in 2013 and 2014 seasons. Data also revealed that rice genotypes are varied in their number of days to maturity. It was clear that GZ7576-10-3-2-1 and Giza179 genotypes were earlier in maturity while, Sakha 101 matured about 143 days (late genotype). These differences among rice genotypes might be attributed to the genetic diversity among all genotypes under this study. Sedeek et al. (2009) and Faruq et al. (2011) observed the variations in heading days of several genotypes. The effect of the interaction between rice genotypes and different locations on duration was significant in both seasons of study as shown in Table (4). Giza179 and GZ7576-10-3-2-1 seemed to be the earliest genotypes under Gemmiza condition in the 2013 and 2014 respectively while Sakha 101 at Sakha took more days to maturity than the other genotypes in the two seasons. 
Table 3: Plant height, duration, flag leaf area and number of panicles per $\mathrm{m}^{2}$ at harvest of tested rice genotypes at different locations in 2013 and 2014 seasons

\begin{tabular}{|c|c|c|c|c|c|c|c|c|}
\hline \multirow[t]{2}{*}{ Factor } & \multicolumn{2}{|c|}{ Plant height $(\mathrm{cm})$} & \multicolumn{2}{|c|}{ Duration (days) } & \multicolumn{2}{|c|}{$\begin{array}{c}\text { Flag leaf area } \\
\left(\mathrm{cm}^{2}\right)\end{array}$} & \multicolumn{2}{|c|}{$\begin{array}{c}\text { No. of panicles } \\
\mathrm{m}^{-2}\end{array}$} \\
\hline & 2013 & 2014 & 2013 & 2014 & 2013 & 2014 & 2013 & 2014 \\
\hline Location: & & & & & & & & \\
\hline Sakha & 96.98 & 98.97 & 126.11 & 125.44 & 27.87 & 29.11 & 503.05 & 526.18 \\
\hline Gemmiza & 97.48 & 100.07 & 126.47 & 125.78 & 29.78 & 32.01 & 522.78 & 546.60 \\
\hline Zarzoura & 98.11 & 101.37 & 125.53 & 126.78 & 28.39 & 30.87 & 504.58 & 540.35 \\
\hline LSD at 0.05 & 0.96 & 1.05 & N.S & N.S & 1.65 & 1.37 & 13.72 & 12.56 \\
\hline Genotype: & & & & & & & & \\
\hline Giza177 & 100.37 & 100.96 & 124.89 & 124.89 & 26.86 & 27.64 & 421.95 & 497.23 \\
\hline Giza178 & 104.77 & 102.85 & 131.22 & 131.89 & 32.41 & 36.82 & 556.10 & 598.05 \\
\hline Sakha101 & 92.27 & 95.54 & 143.22 & 143.00 & 32.79 & 34.51 & 567.50 & 580.55 \\
\hline Sakha105 & 102.82 & 105.93 & 125.33 & 124.89 & 28.45 & 28.35 & 459.18 & 508.33 \\
\hline Sakha106 & 105.72 & 106.45 & 121.44 & 123.78 & 28.60 & 29.59 & 445.55 & 458.33 \\
\hline GZ7576-10-3-2-1 & 98.23 & 98.13 & 119.78 & 120.78 & 22.31 & 24.84 & 452.23 & 445.83 \\
\hline Giza179 & 94.75 & 95.81 & 119.44 & 120.44 & 30.45 & 34.94 & 552.78 & 580.55 \\
\hline GZ9461-4-2-3-1 & 93.30 & 99.53 & 124.89 & 122.44 & 25.57 & 28.39 & 506.95 & 558.60 \\
\hline GZ9523-2-1-1-1 & 95.92 & 102.58 & 126.22 & 124.22 & 36.23 & 37.80 & 588.60 & 621.10 \\
\hline GZ9577-4-1-1 & 94.47 & 101.20 & 126.56 & 124.44 & 27.56 & 28.64 & 538.60 & 546.40 \\
\hline GZ9626-2-1-1 & 91.68 & 92.80 & 123.44 & 126.89 & 27.58 & 28.95 & 516.68 & 538.90 \\
\hline GZ9807-6-3-2-1 & 95.95 & 99.85 & 126.00 & 124.33 & 25.33 & 27.53 & 515.55 & 518.60 \\
\hline LSD at 0.05 & 0.82 & 1.03 & 3.61 & 3.71 & 1.47 & 1.90 & 19.80 & 18.70 \\
\hline Interaction & NS & NS & $\star *$ & $\star \star *$ & ** & * & * & $* *$ \\
\hline
\end{tabular}

Concerning flag leaf area, data in Table (3) indicated that rice genotypes differ significantly in their flag leaf area at different locations. All the rice genotypes produced the highest values of flag leaf area under Gemmiza followed by Zarzoura location. This mainly due to the high soil native content of organic matter, available $\mathrm{NH}_{4}$ and available $\mathrm{NO}_{3}$ of Gemmiza (Table 1). Sahrawat (2005) indicated that microbial activity in a soil drives organic matter decomposition and mineralization processes, leading to release of organically bound plant nutrients in forms available to grow plants. GZ9523-2-1-1-1 gave the highest values of flag leaf area, while, GZ7576-10-3-2-1 recorded the lowest one. The differences among the rice genotypes in their flag leaf area mainly attributed to nature of growth of genotype and plant type. The effect of the interaction between rice genotypes and different locations on flag leaf area were significant in the two seasons of the study as shown in Table (5). The highest values of flag leaf area were obtained by GZ9523-2-1-1-1 in the first season and Giza178 in the second season at Gemmiza. While, the rice genotype of GZ7576-10-32-1 recorded the lowest flag leaf area at the three locations, Sakha, Gemmiza and Zarzoura in 2013 and 2014 seasons. 
Table 4: Duration (days) as affected by the interaction between rice genotype and location in 2013 and 2014 seasons

\begin{tabular}{|l|c|c|c|c|c|c|}
\hline \multirow{2}{*}{ Genotype } & \multicolumn{3}{|c|}{2013} & \multicolumn{3}{c|}{2014} \\
\cline { 2 - 7 } & Sakha & Gemmiza & Zarzoura & Sakha & Gemmiza & Zarzoura \\
\hline Giza177 & 125.00 & 125.67 & 124.00 & 124.33 & 125.33 & 125.00 \\
Giza178 & 134.33 & 130.00 & 129.33 & 131.00 & 131.33 & 133.33 \\
Sakha101 & 144.67 & 143.67 & 141.33 & 143.67 & 142.33 & 143.00 \\
Sakha105 & 123.67 & 126.67 & 125.67 & 126.67 & 124.00 & 124.00 \\
Sakha106 & 121.67 & 122.67 & 120.00 & 121.33 & 124.67 & 125.33 \\
GZ7576-10-3-2-1 & 119.00 & 121.67 & 118.67 & 121.67 & 119.00 & 121.67 \\
Giza179 & 118.67 & 118.33 & 121.33 & 119.67 & 121.00 & 120.67 \\
GZ9461-4-2-3-1 & 124.67 & 125.33 & 124.67 & 122.00 & 121.00 & 124.33 \\
GZ9523-2-1-1-1 & 125.33 & 126.00 & 127.33 & 122.00 & 124.00 & 126.67 \\
GZ9577-4-1-1 & 126.00 & 127.00 & 126.67 & 123.33 & 124.67 & 125.33 \\
GZ9626-2-1-1 & 124.67 & 123.00 & 122.67 & 125.33 & 129.00 & 126.33 \\
GZ9807-6-3-2-1 & 125.67 & 127.67 & 124.67 & 124.33 & 123.00 & 125.67 \\
\hline LSD at 0.05 & 4.17 & & 4.35 & \\
\hline
\end{tabular}

Table 5: Flag leaf area $\left(\mathrm{cm}^{2}\right)$ as affected by the interaction between rice genotype and location in 2013 and 2014 seasons

\begin{tabular}{|l|c|c|c|c|c|c|}
\hline \multicolumn{1}{|c|}{ Genotype } & \multicolumn{3}{|c|}{2013} & \multicolumn{3}{c|}{2014} \\
\cline { 2 - 7 } & Sakha & Gemmiza & Zarzoura & Sakha & Gemmiza & Zarzoura \\
\hline Giza177 & 26.54 & 26.71 & 27.33 & 27.53 & 28.34 & 27.04 \\
Giza178 & 31.60 & 32.66 & 32.98 & 34.47 & 39.24 & 36.75 \\
Sakha101 & 31.19 & 35.53 & 31.65 & 32.48 & 35.93 & 35.12 \\
Sakha105 & 27.88 & 28.84 & 28.65 & 27.15 & 30.16 & 27.73 \\
Sakha106 & 27.08 & 28.92 & 29.79 & 27.07 & 30.87 & 30.83 \\
GZ7576-10-3-2-1 & 20.51 & 24.66 & 21.75 & 22.87 & 26.51 & 25.13 \\
Giza179 & 30.13 & 31.87 & 29.36 & 32.29 & 38.84 & 33.70 \\
GZ9461-4-2-3-1 & 25.53 & 26.93 & 24.26 & 26.73 & 28.50 & 29.93 \\
GZ9523-2-1-1-1 & 34.83 & 37.22 & 36.64 & 36.52 & 38.76 & 38.13 \\
GZ9577-4-1-1 & 28.07 & 28.86 & 25.74 & 28.06 & 28.87 & 28.99 \\
GZ9626-2-1-1 & 26.20 & 29.15 & 27.40 & 27.62 & 30.28 & 28.95 \\
GZ9807-6-3-2-1 & 24.88 & 25.96 & 25.16 & 26.65 & 27.82 & 28.11 \\
\hline LSD at 0.05 & \multicolumn{7}{|c|}{1.92} & \multicolumn{4}{c}{2.52} & \\
\hline
\end{tabular}

Data in Table (3) reveled that rice plants which planted at Gemmiza location produced the highest values of number of panicles per $\mathrm{m}^{2}$ followed by those planted at Zarzoura location. This mainly due to high soil organic matter as well as soil native in available elements and low Ec at Gemmiza location which is suitable for the growth of rice plants. (Table 1). The high content of available contents of minerals fertile specially $\mathrm{N}$ and $\mathrm{P}$ resulted in increasing the metabolite stream translocated from source to sink which increase the number of panicles per unit area. Data showed also that number of panicles per $\mathrm{m}^{2}$ varied significantly among the tested genotypes (Table 3.). The genotype GZ9523-2-1-1-1 produced the highest number of panicles $\mathrm{m}^{2}$ followed by Sakha101 in both seasons. The effect of the interaction between rice genotypes and different locations on number of panicles per $\mathrm{m}^{2}$ at harvest, which significant in both seasons of study is shown 
in Table (6). The rice genotype GZ9523-2-1-1-1 recorded the highest number of panicles per $\mathrm{m}^{2}$ at Zarzoura location in the two seasons, while, Sakha 106 produced the lowest number of panicles per $\mathrm{m}^{2}$ at Gemmiza and Zarzoura locations in the two seasons, respectively. The prevailing condition of Gemmiza recorded significantly the longest panicle (Table 7).

Table 6: Number of panicles per $\mathrm{m}^{2}$ as affected by the interaction between rice genotype and location in 2013 and 2014 seasons

\begin{tabular}{|l|c|c|c|c|c|c|}
\hline \multirow{2}{*}{ Genotype location } & \multicolumn{5}{|c|}{2013} & \multicolumn{3}{c|}{2014} \\
\cline { 2 - 7 } & Sakha & $\begin{array}{c}\text { Gemmiz } \\
\text { a }\end{array}$ & Zarzoura & Sakha & Gemmiz & Zarzoura \\
\hline Giza177 & 433.33 & 441.68 & 400.00 & 475.00 & 500.00 & 516.68 \\
Giza178 & 575.00 & 541.68 & 558.33 & 583.33 & 616.68 & 608.33 \\
Sakha101 & 550.00 & 491.68 & 558.33 & 566.68 & 591.68 & 583.33 \\
Sakha105 & 458.33 & 466.68 & 416.68 & 491.68 & 508.33 & 525.00 \\
Sakha106 & 391.68 & 358.33 & 433.33 & 483.33 & 466.68 & 458.33 \\
GZ7576-10-3-2-1 & 516.68 & 483.33 & 516.68 & 508.33 & 450.00 & 533.33 \\
Giza179 & 566.68 & 558.33 & 533.33 & 558.33 & 608.33 & 575.00 \\
GZ9461-4-2-3-1 & 516.68 & 475.00 & 591.68 & 558.33 & 566.68 & 575.00 \\
GZ9523-2-1-1-1 & 566.68 & 583.33 & 600.00 & 575.00 & 641.68 & 658.33 \\
GZ9577-4-1-1 & 541.68 & 541.68 & 558.33 & 591.68 & 533.33 & 608.33 \\
GZ9626-2-1-1 & 508.33 & 516.68 & 525.00 & 566.68 & 533.33 & 516.68 \\
GZ9807-6-3-2-1 & 516.68 & 533.33 & 583.33 & 550.00 & 525.00 & 566.68 \\
\hline LSD at 0.05 & \multicolumn{7}{|c|}{21.11} \\
\hline
\end{tabular}

Table 7: Panicle length, number of filled grains per panicle, panicle weight and 1000-grain weight of tested rice genotypes at different locations in 2013 and 2014 seasons

\begin{tabular}{|l|c|c|c|c|c|c|c|c|}
\hline \multirow{2}{*}{ Factor } & \multicolumn{2}{c|}{$\begin{array}{c}\text { Panicle length } \\
\text { (cm) }\end{array}$} & \multicolumn{2}{c|}{$\begin{array}{c}\text { Filled grains } \\
\text { panicle }\end{array}$} & \multicolumn{2}{c|}{$\begin{array}{c}\text { Panicle weight } \\
(\mathrm{g})\end{array}$} & \multicolumn{2}{c|}{$\begin{array}{c}1000 \text {-grain } \\
\text { weight }(\mathrm{g})\end{array}$} \\
\cline { 2 - 9 } & 2013 & 2014 & 2013 & 2014 & 2013 & 2014 & 2013 & 2014 \\
\hline Location: & & & & & & & & \\
Sakha & 20.618 & 20.834 & 154.11 & 159.69 & 3.153 & 3.363 & 26.568 & 26.928 \\
Gemmiza & 21.155 & 22.453 & 162.17 & 170.61 & 3.306 & 3.545 & 27.023 & 27.489 \\
Zarzoura & 20.520 & 21.286 & 157.11 & 161.42 & 3.249 & 3.337 & 26.781 & 27.139 \\
LSD at 0.05 & 0.370 & 0.250 & 2.28 & 2.27 & 0.106 & 0.027 & 0.112 & 0.104 \\
\hline Genotype: & & & & & & & & \\
Giza177 & 17.136 & 18.148 & 145.33 & 147.11 & 3.121 & 3.390 & 27.088 & 27.924 \\
Giza178 & 24.949 & 25.428 & 175.78 & 177.89 & 2.930 & 3.111 & 21.889 & 22.229 \\
Sakha101 & 19.983 & 20.369 & 176.33 & 176.67 & 3.879 & 4.171 & 28.708 & 29.023 \\
Sakha105 & 19.083 & 17.687 & 153.11 & 163.00 & 3.434 & 3.458 & 27.796 & 27.967 \\
Sakha106 & 20.532 & 22.298 & 153.44 & 163.22 & 3.382 & 3.362 & 28.513 & 28.591 \\
GZ7576-10-3-2-1 & 16.837 & 17.289 & 156.56 & 159.11 & 2.190 & 2.470 & 24.362 & 24.738 \\
Giza179 & 23.424 & 24.610 & 159.89 & 162.78 & 3.673 & 3.821 & 27.752 & 28.229 \\
GZ9461-4-2-3-1 & 18.982 & 19.812 & 146.78 & 160.00 & 3.121 & 3.259 & 26.777 & 27.142 \\
GZ9523-2-1-1-1 & 25.071 & 26.539 & 173.22 & 177.11 & 4.202 & 4.353 & 26.966 & 27.342 \\
GZ9577-4-1-1 & 24.464 & 24.977 & 163.00 & 171.67 & 3.341 & 3.612 & 27.007 & 27.121 \\
GZ9626-2-1-1 & 19.223 & 21.030 & 148.33 & 155.89 & 2.494 & 2.740 & 27.093 & 27.592 \\
GZ9807-6-3-2-1 & 19.486 & 20.106 & 141.78 & 152.44 & 3.062 & 3.233 & 27.537 & 28.322 \\
LSD at 0.05 & 0.466 & 0.321 & 12.76 & 13.23 & 0.121 & 0.082 & 0.200 & 0.216 \\
\hline Interaction & $\star *$ & $* *$ & $* *$ & $* *$ & NS & $*$ & $* *$ & $*$ \\
\hline
\end{tabular}

${ }^{*},{ }^{* *}$ and $N S$ indicate $P<0.05, P<0.01$ and not significant, respectively. 
The high soil fertility at Gemmiza location plots might suggest cause that higher soil fertility caused the longest panicle (Table 7). Regarding to rice genotypes, the twelve genotypes differ significantly in this trait. The genotype GZ9523-2-1-1-1 gave the longest panicle, while the genotype GZ7576 recorded the shortest one. These differences among rice genotypes mainly due to genetic background. Data in Table (8) showed that the interaction between location and rice genotype was significant for panicle length. The genotype GZ9523-21-1-1 produced the longest panicle at Gemmiza during 2013 and 2014.

Table 8: Panicle length $(\mathrm{cm})$ as affected by the interaction between rice genotype and location in 2013 and 2014 seasons

\begin{tabular}{|l|c|c|c|c|c|c|}
\hline \multirow{2}{*}{ Genotype } & \multicolumn{3}{|c|}{2013} & \multicolumn{3}{c|}{2014} \\
\cline { 2 - 7 } & Sakha & Gemmiza & Zarzoura & Sakha & Gemmiza & Zarzoura \\
\hline Giza177 & 16.987 & 17.933 & 16.487 & 17.773 & 19.857 & 16.813 \\
Giza178 & 24.040 & 25.657 & 25.150 & 24.400 & 26.180 & 25.703 \\
Sakha101 & 19.897 & 20.283 & 19.770 & 19.780 & 21.317 & 20.010 \\
Sakha105 & 18.993 & 18.933 & 19.323 & 18.683 & 18.143 & 16.233 \\
Sakha106 & 20.053 & 20.970 & 20.573 & 20.013 & 24.900 & 21.980 \\
GZ7576-10-3-2-1 & 16.680 & 17.010 & 16.820 & 16.910 & 17.057 & 17.900 \\
Giza179 & 23.010 & 23.677 & 23.587 & 22.847 & 26.060 & 24.923 \\
GZ9461-4-2-3-1 & 19.023 & 19.470 & 18.453 & 19.020 & 20.497 & 19.920 \\
GZ9523-2-1-1-1 & 24.947 & 25.797 & 24.470 & 25.067 & 27.997 & 26.553 \\
GZ9577-4-1-1 & 24.300 & 24.790 & 24.303 & 25.600 & 25.053 & 24.277 \\
GZ9626-2-1-1 & 19.480 & 19.507 & 18.683 & 20.033 & 21.680 & 21.377 \\
GZ9807-6-3-2-1 & 20.007 & 19.833 & 18.617 & 19.883 & 20.693 & 19.740 \\
\hline LSD at 0.05 & \multicolumn{7}{|c|}{0.81} \\
\hline
\end{tabular}

Data in Table (7) showed that locations and genotypes were found to affect number of filled grains per panicle. Gemmiza location recorded the highest values of number of filled grains per panicle comparing with the other two locations. Data in Table (7) indicted also that there was significant differences among the twelve rice genotypes for this trait in two seasons. Giza178, Sakha101 and GZ9523-2-1-1-1 recorded the highest number of filled grains per panicle in the two successive seasons. While, GZ9807-6-3-2-1 (in the first season) and Giza177 (in the second season) recorded the lowest number. The differences in number of filled grains panicle ${ }^{-1}$ could be attributed to genotypes and environment. Similar trend was found by Sedeek et al. (2009).

Data reported in Table (9) indicated that the rice genotypes under study responded differently under different environments for this trait. The highest number of filled grains per panicle was obtained by GZ9523-2-1-1-1 genotype followed by Sakha101 and Giza178 genotype at Gemmiza location. 
Table 9: Number of filled grains per panicle as affected by the interaction between rice genotype and location in 2013 and 2014 seasons

\begin{tabular}{|l|c|c|r|r|r|r|}
\hline \multirow{2}{*}{ Genotype } & \multicolumn{3}{|c|}{2013} & \multicolumn{3}{c|}{2014} \\
\cline { 2 - 7 } & Sakha & Gemmiza & Zarzoura & Sakha & Gemmiza & Zarzoura \\
\hline Giza177 & 144.00 & 145.67 & 146.33 & 144.33 & 153.33 & 143.67 \\
Giza178 & 174.67 & 178.33 & 174.33 & 176.33 & 178.67 & 178.67 \\
Sakha101 & 176.00 & 179.00 & 174.00 & 174.33 & 181.00 & 174.67 \\
Sakha105 & 149.00 & 156.33 & 154.00 & 154.67 & 166.00 & 168.33 \\
Sakha106 & 149.67 & 154.67 & 156.00 & 161.00 & 167.33 & 161.33 \\
GZ7576-10-3-2-1 & 141.67 & 165.00 & 163.00 & 144.33 & 167.33 & 165.67 \\
Giza179 & 157.67 & 160.67 & 161.33 & 163.33 & 171.67 & 153.33 \\
GZ9461-4-2-3-1 & 144.67 & 149.33 & 146.33 & 155.33 & 166.33 & 158.33 \\
GZ9523-2-1-1-1 & 163.00 & 191.33 & 165.33 & 163.33 & 197.33 & 170.67 \\
GZ9577-4-1-1 & 163.67 & 164.00 & 161.33 & 171.00 & 173.33 & 170.67 \\
GZ9626-2-1-1 & 145.67 & 158.00 & 141.33 & 159.33 & 163.33 & 145.00 \\
GZ9807-6-3-2-1 & 139.67 & 143.67 & 142.00 & 149.00 & 161.67 & 146.67 \\
\hline LSD at 0.05 & \multicolumn{7}{|c|}{14.86} & & 15.06 & \\
\hline
\end{tabular}

Panicle weight was significantly affected by location and genotypes in the two seasons (Table 7). Panicle weight values for the two seasons at Gemmiza location was heavier than other locations. The genotype GZ9523-2-1-1-1 produced the heaviest panicle followed by Sakha101. While, the lightest panicle produced by GZ7576-10-3-21 genotype. Concerning locations $x$ genotypes interaction, the interaction was significant in 2014 only (Tables 7 and 10). The highest values were obtained from genotype GZ9523-2-1-1-1 which grown at Gemmiza region. But the lowest panicle weight values were reported at Zarzoura region by GZ7576-10-3-2-1 rice genotype.

Table 10: Panicle weight $(\mathrm{g})$ as affected by the interaction between rice genotype and location in 2013 and 2014 seasons

\begin{tabular}{|c|c|c|c|}
\hline Genotype Location & Sakha & Gemmiza & Zarzoura \\
\hline Giza177 & 3.267 & 3.547 & 3.357 \\
\hline Giza178 & 3.047 & 3.173 & 3.113 \\
\hline Sakha101 & 4.107 & 4.233 & 4.173 \\
\hline Sakha105 & 3.433 & 3.550 & 3.390 \\
\hline Sakha106 & 3.147 & 3.550 & 3.390 \\
\hline GZ7576-10-3-2-1 & 2.360 & 2.927 & 2.123 \\
\hline Giza179 & 3.883 & 3.790 & 3.790 \\
\hline GZ9461-4-2-3-1 & 3.140 & 3.580 & 3.057 \\
\hline GZ9523-2-1-1-1 & 4.373 & 4.483 & 4.203 \\
\hline GZ9577-4-1-1 & 3.617 & 3.680 & 3.540 \\
\hline GZ9626-2-1-1 & 2.497 & 2.893 & 2.830 \\
\hline GZ9807-6-3-2-1 & 3.483 & 3.137 & 3.080 \\
\hline LSD at 0.05 & & 0.140 & \\
\hline
\end{tabular}

Data in Table (7) indicated that 1000-grain weight of rice genotypes was affected significantly by different locations. Rice genotypes at Gemmiza location produced the heaviest 1000-grain 
weight. The increase in grain yield under Gemmiza condition may be due to high soil native in organic matter, available N, P and K (Table 1). Data revealed also that, differences among the rice genotypes in their 1000-grain weight were significant in the two seasons. Sakha101 gave the highest value of 1000-grain followed by Sakha106 While, Giza 178 recorded the lowest one. These differences may be due to the differences in their genetic structures. These results are in agreement with those obtained by Sedeek et al. (2009) and Faruq et al. (2011). Data in Table (11) showed the effect of interaction between rice genotypes and location on 1000-grain weight. Sakha101 produced the highest values of 1000-grain weight followed by Sakha106 whatever the location.

Table 11: 1000-grain weight $(\mathrm{g})$ as affected by the interaction between rice genotype and location in 2013 and 2014 seasons

\begin{tabular}{|l|c|c|c|c|c|c|}
\hline \multirow{2}{*}{ Location } & \multicolumn{3}{|c|}{2013} & \multicolumn{2}{c|}{2014} \\
\cline { 2 - 7 } & Sakha & Gemmiza & Zarzoura & Sakha & Gemmiza & Zarzoura \\
\hline Giza177 & 27.033 & 27.163 & 27.067 & 27.930 & 28.207 & 27.637 \\
Giza178 & 21.603 & 22.877 & 21.187 & 22.010 & 22.993 & 21.683 \\
Sakha101 & 28.607 & 28.607 & 28.910 & 28.393 & 29.727 & 28.950 \\
Sakha105 & 27.453 & 28.007 & 27.927 & 27.713 & 28.127 & 28.060 \\
Sakha106 & 28.403 & 28.697 & 28.440 & 28.240 & 28.857 & 28.677 \\
GZ7576-10-3-2-1 & 24.047 & 24.263 & 24.777 & 24.440 & 24.993 & 24.780 \\
Giza179 & 27.470 & 28.150 & 27.637 & 28.083 & 28.457 & 28.147 \\
GZ9461-4-2-3-1 & 27.300 & 26.110 & 26.920 & 27.643 & 26.660 & 27.123 \\
GZ9523-2-1-1-1 & 26.717 & 27.110 & 27.070 & 27.143 & 27.420 & 27.463 \\
GZ9577-4-1-1 & 26.057 & 27.707 & 27.257 & 26.093 & 28.023 & 27.247 \\
GZ9626-2-1-1 & 27.080 & 27.147 & 27.053 & 27.057 & 28.040 & 27.680 \\
GZ9807-6-3-2-1 & 27.047 & 28.433 & 27.130 & 28.383 & 28.363 & 28.220 \\
\hline LSD at 0.05 & \multicolumn{7}{|c|}{0.34} & & 0.36 & \\
\hline
\end{tabular}

Data in Table (12) indicated that grain yield was affected significantly by location. The rice genotypes recorded the highest values of grain yield at Gemmiza region, surpassing significantly with other two locations. Soil structure, texture and fertility have contributed towards this variation. Unpredictable environmental factors such as temperature and humidity, even at a single location may contribute to genotype by environmental interaction over year. Anputhas et al. (2011) and Mosavi et al. (2012) reported similar trend.

Regarding rice genotypes, they differed significantly in their grain yield in the two seasons of the study, Table (12). Five and six genotypes produced more than $10 \mathrm{t} \mathrm{ha}^{-1}$ in 2013 and 2014 respectively. GZ9523-2-1-1-1 produced the highest grain yield followed by Sakha101 and Giza179. On the other hand, GZ9626-2-1-1 and GZ9807-6-3-2-1 produced the lowest grain yield. The superiority of GZ9523-2-1-1-1 and Sakha 101 rice genotypes in grain yield might be due to their high values of each of flag leaf area, number of panicles $\mathrm{m}^{-}$ ${ }^{2}$, number of filled grains panicle ${ }^{-1}$ and panicle weight. Jeng et al. 
(2006) revealed that the grain yield for rice was positive correlated significantly with the percentage of filled grains, the number of panicle per unit ground area, 1000-grains weight, and the number of grains per panicle. These results are in agreement with those obtained by Sedeek et al. (2009).

Table 12: Grain yield, hulling, milling and head rice of tested rice genotypes at different locations in 2013 and 2014 seasons

\begin{tabular}{|l|c|c|c|c|c|c|c|c|}
\hline \multirow{2}{*}{ Factor } & \multicolumn{2}{|c|}{$\begin{array}{c}\text { Grain yield } \\
\text { (t ha-1 })\end{array}$} & \multicolumn{2}{c|}{ Hulling (\%) } & \multicolumn{2}{c|}{ Milling (\%) } & \multicolumn{2}{c|}{ Head rice (\%) } \\
\cline { 2 - 9 } & 2013 & 2014 & 2013 & 2014 & 2013 & 2014 & 2013 & 2014 \\
\hline Location: & & & & & & & & \\
Sakha & 8.974 & 9.318 & 80.186 & 80.646 & 70.34 & 69.867 & 56.39 & 58.03 \\
Gemmiza & 9.479 & 9.958 & 80.076 & 80.369 & 69.13 & 69.152 & 56.95 & 56.86 \\
Zarzoura & 9.037 & 9.433 & 80.523 & 80.930 & 69.74 & 70.127 & 56.46 & 57.05 \\
LSD at 0.05 & 0.345 & 0.253 & NS & NS & NS & NS & NS & NS \\
\hline Genotype: & & & & & & & & \\
Giza177 & 8.959 & 9.230 & 78.897 & 80.972 & 69.31 & 70.179 & 56.21 & 54.62 \\
Giza178 & 10.252 & 10.383 & 78.270 & 78.558 & 67.01 & 66.682 & 47.58 & 48.37 \\
Sakha101 & 10.750 & 10.876 & 79.498 & 79.752 & 69.80 & 68.860 & 56.45 & 58.60 \\
Sakha105 & 9.537 & 10.088 & 80.370 & 80.268 & 69.68 & 69.373 & 58.38 & 59.82 \\
Sakha106 & 9.138 & 9.461 & 79.628 & 81.016 & 68.71 & 69.243 & 56.74 & 57.83 \\
GZ7576-10-3-2-1 & 7.716 & 8.311 & 79.218 & 79.560 & 69.82 & 66.203 & 56.87 & 59.37 \\
Giza179 & 10.492 & 10.694 & 82.488 & 82.859 & 72.11 & 72.473 & 60.22 & 61.16 \\
GZ9461-4-2-3-1 & 8.004 & 8.338 & 80.560 & 80.394 & 69.75 & 69.284 & 57.27 & 57.33 \\
GZ9523-2-1-1-1 & 11.010 & 11.316 & 81.720 & 82.627 & 70.39 & 71.752 & 57.86 & 59.60 \\
GZ9577-4-1-1 & 10.326 & 10.336 & 80.062 & 79.700 & 69.28 & 69.290 & 55.75 & 53.35 \\
GZ9626-2-1-1 & 6.550 & 7.850 & 83.000 & 83.226 & 72.22 & 73.130 & 57.79 & 59.07 \\
GZ9807-6-3-2-1 & 7.224 & 7.956 & 79.429 & 78.847 & 68.74 & 70.114 & 58.09 & 58.59 \\
LSD at 0.05 & 0.475 & 0.262 & 0.6308 & 0.456 & 1.04 & 0.702 & 1.224 & 1.104 \\
\hline Interaction & $* *$ & $*$ & NS & NS & NS & NS & NS & NS \\
\hline
\end{tabular}

${ }^{*},{ }^{* *}$ and $N S$ indicate $P<0.05, P<0.01$ and not significant, respectively.

It is important to note that the tested genotypes were varied in their interaction with the environmental factor and exhibited different responses to the different locations (Table 13.). GZ9523-2-1-1-1 and Sakha101 produced the highest grain yield under Gemmiza condition. Superiority of the GZ9523-2-1-1-1 and Sakha101 genotypes at Gemmiza was due to their relative advantages in their yield components. Grain yield depends on genotype, environment and their interaction with each other. Under the same management conditions, variation in grain yield is principally explained by the effects of genotype and environment (Dingkuhn et al., 2006). Interaction between these two explanatory variables gives insight for identifying genotype suitable for different environments. The high yielding genotypes Giza178, Sakha101, Giza179, GZ9523-2-1-1-1 and GZ9577-4-1-1 cover a broad range of phenological and physiological traits across different environments.

These results indicate that genotypes under study responded differently to different environmental conditions suggesting the 
importance of the evaluation genotypes under different environments in order to identify the best genetic make up for a particular environment. Tariku et al. (2013) reported that the significant genotype $x$ environment interaction effects on grain yield demonstrated that genotypes responded differently to the variation in environmental conditions of location which indicated the necessity of testing rice genotypes at multiple locations.

Table 13: Grain yield $\mathrm{t} \mathrm{ha}^{-1}$ as affected by the interaction between rice genotype and location in 2013 and 2014 seasons

\begin{tabular}{|l|c|c|c|c|c|c|}
\hline \multirow{2}{*}{ Genotype } & \multicolumn{3}{|c|}{2013} & \multicolumn{3}{c|}{2014} \\
\cline { 2 - 7 } & Sakha & Gemmiza & Zarzoura & Sakha & Gemmiza & Zarzoura \\
\hline Giza177 & 8.860 & 9.167 & 8.850 & 8.810 & 9.873 & 9.007 \\
Giza178 & 10.040 & 10.633 & 10.083 & 10.180 & 10.777 & 10.193 \\
Sakha101 & 10.613 & 10.883 & 10.753 & 11.020 & 11.330 & 10.277 \\
Sakha105 & 9.477 & 9.600 & 9.533 & 9.603 & 10.477 & 10.183 \\
Sakha106 & 9.103 & 9.100 & 9.210 & 9.287 & 9.800 & 9.297 \\
GZ7576-10-3-2-1 & 7.287 & 8.537 & 7.323 & 8.143 & 8.720 & 8.070 \\
Giza179 & 10.300 & 10.350 & 10.827 & 10.787 & 10.783 & 10.513 \\
GZ9461-4-2-3-1 & 7.640 & 8.287 & 8.087 & 7.823 & 8.897 & 8.293 \\
GZ9523-2-1-1-1 & 10.950 & 11.513 & 10.567 & 11.053 & 11.737 & 11.157 \\
GZ9577-4-1-1 & 10.550 & 10.657 & 9.770 & 10.020 & 10.557 & 10.430 \\
GZ9626-2-1-1 & 6.093 & 7.503 & 6.053 & 7.397 & 8.283 & 7.870 \\
GZ9807-6-3-2-1 & 6.773 & 7.517 & 7.383 & 7.693 & 8.263 & 7.910 \\
\hline LSD at 0.05 & \multicolumn{7}{|c|}{0.66} \\
\hline
\end{tabular}

Grain quality characters i.e. hulling, milling and head rice percentages were presented in Table (12). Data showed that the differences in all grain quality characters among the three locations were not significant in both the seasons, however the differences among genotypes were significant. The highest hulling percentage and milling percentage were obtained from GZ9626-2-1-1. Giza179 produced statistically identical hulling percentage and milling percentage compared with GZ9626-2-1-1. The highest value of head rice percentage was obtained from Giza179. On the other hand, Giza178 produced the lowest values of grain quality characters in the two successive seasons. Jeng et al. (2006) indicated that superior grain quality of rice cultivars related significantly to 1000 -grain weight and more uniform grain development within a panicle. The interaction between rice genotype and location had no significant effect on all studied grain quality characters.

Concerning to stem borer infection, data in Table (14) shows that the genotypes, locations and interaction were significant for stem borer infestation (white head percentage). It could be observed that the highest percentage of white head was obtained from rice genotypes at Gemmiza region. Sakha101 was resistance while, Giza177, Sakha105, Giza179, GZ9461-4-2-3-1, GZ9577-4-1-1, GZ9626-2-1-1 
and GZ9807-6-3-2-1 were moderate resistant. On the other hand, Sakha106, GZ7576-10-3-2-1 and GZ9523-2-1-1-1 were moderate susceptible and Giza178 was susceptible to stem borer.

Concerning the blast reaction, the differences among the locations were not significant in both seasons. For blast reaction of rice genotypes, most of rice genotypes were resistant to rice blast over all different locations in the two seasons except Sakha 101, which was highly susceptible to rice blast in both seasons (Table 14). Also, the results signifies that no interaction between genotypes and locations was found for this trait.

Table 14: Stem borer and blast reaction of tested rice genotypes at different locations in 2013 and 2014 seasons

\begin{tabular}{|l|c|c|c|c|c|c|}
\hline \multirow{2}{*}{ Factor } & \multicolumn{3}{c|}{ Stem borer \% } & \multicolumn{3}{c|}{ Blast reaction } \\
\cline { 2 - 7 } & 2013 & 2014 & Reaction & 2013 & 2014 & Reaction \\
\hline Location: & & & & & & \\
Sakha & 5.884 & 5.197 & - & 2.389 & 2.111 & - \\
Gemmiza & 6.359 & 5.529 & - & 2.403 & 2.111 & - \\
Zarzoura & 6.147 & 5.270 & - & 2.694 & 2.750 & - \\
LSD at 0.05 & 0.1482 & 0.2150 & - & NS & NS & - \\
\hline Genotype: & & & & & & \\
Giza177 & 5.778 & 4.744 & MR & 2.000 & 1.444 & $\mathrm{R}$ \\
Giza178 & 13.602 & 11.944 & $\mathrm{~S}$ & 1.722 & 1.444 & $\mathrm{R}$ \\
Sakha101 & 2.248 & 2.027 & $\mathrm{R}$ & 7.444 & 6.444 & $\mathrm{~S}$ \\
Sakha105 & 5.400 & 4.667 & $\mathrm{MR}$ & 1.889 & 2.111 & $\mathrm{R}$ \\
Sakha106 & 6.299 & 5.333 & $\mathrm{MS}$ & 1.556 & 1.889 & $\mathrm{R}$ \\
GZ7576-10-3-2-1 & 7.444 & 6.711 & $\mathrm{MS}$ & 3.444 & 3.333 & $\mathrm{MR}$ \\
Giza179 & 5.667 & 5.611 & $\mathrm{MR}$ & 1.111 & 1.000 & $\mathrm{R}$ \\
GZ9461-4-2-3-1 & 4.667 & 3.600 & $\mathrm{MR}$ & 1.889 & 1.222 & $\mathrm{R}$ \\
GZ9523-2-1-1-1 & 7.730 & 7.644 & $\mathrm{MS}$ & 3.111 & 3.556 & $\mathrm{MR}$ \\
GZ9577-4-1-1 & 6.263 & 2.622 & $\mathrm{MR}$ & 2.556 & 2.000 & $\mathrm{MR}$ \\
GZ9626-2-1-1 & 2.597 & 3.656 & $\mathrm{MR}$ & 1.444 & 1.556 & $\mathrm{R}$ \\
GZ9807-6-3-2-1 & 5.867 & 5.422 & $\mathrm{MR}$ & 1.778 & 1.889 & $\mathrm{R}$ \\
LSD at 0.05 & 0.406 & 0.3869 & - & 0.3879 & 0.3612 & - \\
\hline Interaction & $\mathrm{NS}$ & $\mathrm{NS}$ & - & $\mathrm{NS}$ & $\mathrm{NS}$ & - \\
\hline
\end{tabular}

(R) Resistance, (MR) Moderately resistance, (MS) Moderately susceptible, (S) Susceptible, (HS) highly susceptible. ${ }^{*}{ }^{* \star}$ and NS indicate $P<0.05, P<0.01$ and not significant, respectively.

\section{CONCLUSION}

The twelve genotypes under study responded differently to the different environmental conditions suggesting the importance of the intensive evaluation of genotypes under different environments in order to identify the best genetic makeup specify for a particular environment. The rice genotypes Giza178, Sakha101, Giza179, GZ9523-2-1-1-1 and GZ9577-4-1-1 have a good adaptation under different environmental conditions. 


\section{REFERENCE}

Anonymous,. 2009. Food and Agriculture Organization of the United Nations (FAO). The state of food security in the world, p. 1-30.

Anputhas, M., S. Samita, D. Sumith, and De. Z. Abeysiriwardena. 2011. Stability and adaptability analysis of rice cultivars using environment-centered yield in two-way ANOVA model. Commun. in Biometry and Crop Sci. 6( 2): 80-86.

Black, C.A., D.D. Evans, J.L. White, L.E. Ensminger and F.E. Clark. 1965. "Methods of Soil Analysis. Part 2- Chemical and Microbiological Properties". Am. Soc. of Agron., Inc., Publisher, Madison, Wisconsin, USA.

Dingkuhn, M., D.Luquet, H.Kim, L. Tambour, A. Clement-Vidal. 2006. EcoMeristem, a model of morphogenesis and competition among sinks in rice. 2. Simulating genotype responses to phosphorus deficiency. Funct. Plant Biol. 33(4): 325-337.

Faruq. G., Y. Hui Yin, A. Masitah, N. Afnierna, Nazia Abdul Majid, Norzulaani Khalid, and M. Osman. 2011. Analysis of aroma and yield components of aromatic rice in Malaysian tropical environment. AJCS. 5(11):1318-1325.

Gomez, K.A. and A.A. Gomez. 1984. Statistical procedure for agicultural research. $2^{\text {nd }}$ Ed. Johin Wiley Sons. New yourk. USA.

IRRI, 1996. Standard Evaluation System for rice. $3^{\text {rd }}$ ed. International Rice Research Institute, Los Banos, Philippines

Jeng, T.L., T.H. Tseng, C.S. Wang, C.L. Chen, and J.M. Sung. 2006. Yield and grain uniformity in contrasting rice genotypes suitable for different growth environments. Field Crop. Res. 99:59-66.

Metwally, T. F., S. A. A. Hammoud, M.M. H. El-Malky, and S.M. Bassiouni. 2014. Genetic variability and performance of some promising rice genotypes as affected by nitrogen fertilizer under salt stress condition. Munufiya J. Agric. Res. 39: 2(2): 685-702

Mosavia, A.A., N.B. Jelodarb, and K. Kazemitabara. 2012. Environmental responses and stability analysis for grain yield of some rice genotypes. Ann. Biol. Res. 3(11):5110-5113.

Sahrawat, K. L. 2005. Fertility and organic matter in submerged rice soils. Curr. Sci. 88(5): 735-739.

Sedeek, S.E.M., S.A.A. Hammoud, M.H. Ammar, and T.F. Metwally. 2009. Genetic variability, heritability, genetic advance and cluster analysis for some physiological traits and grain yield and its components in rice (Oryza sativa L.). J. Agric. Res. Kaferelsheikh Univ. 35 (3):858-878.

Shrestha SP, F. Asch F, J. Dusserre J, A. Ramanantsoanirine A, and H. Brueck. H, 2012. Climate effects on yield components as affected by genotypic responses to variable environmental conditions in upland rice systems at different altitudes. Field Crops Res. 134:216-228.

Tariku, S., T. Lakew, M. Bitew, and M. Asfaw. 2013. Genotype by environment interaction and grain yield stability analysis of rice 
(Oryza sativa L.) genotypes evaluated in north western Ethiopia. Net J. Agric. Sci. 1(1):10-16.

$$
\text { دراسة سلوك بعض التراكيب الوراثية المبشرة للأرز تحت مواقع مختلفة }
$$

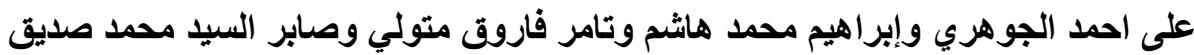

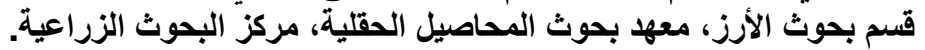

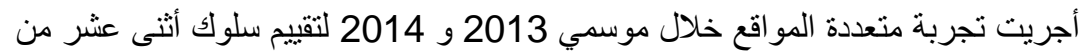

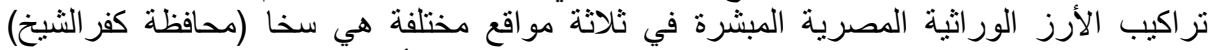

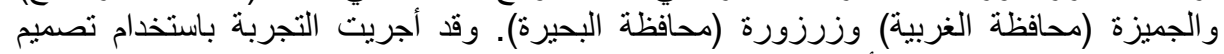

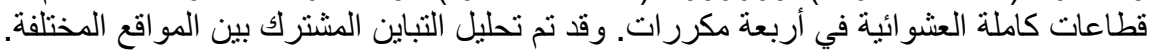

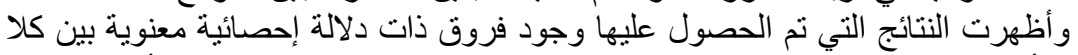

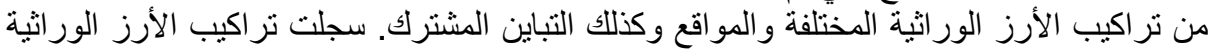

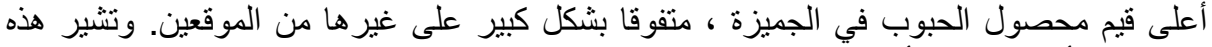

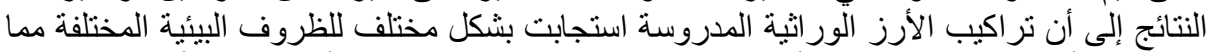

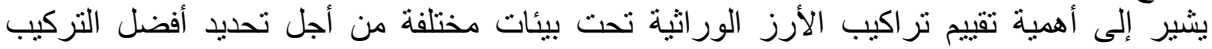

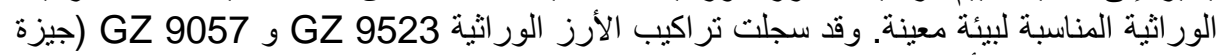

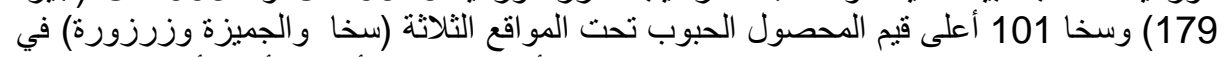

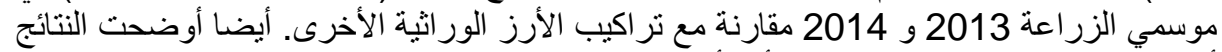

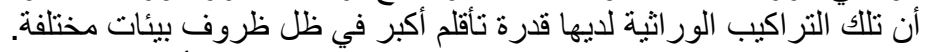

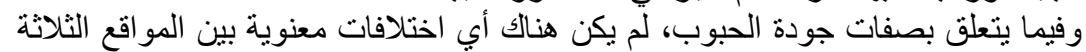

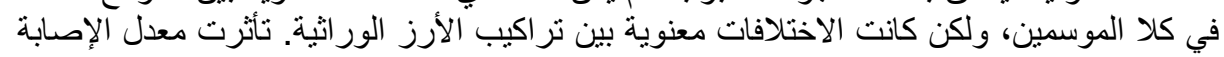

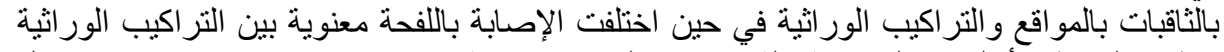

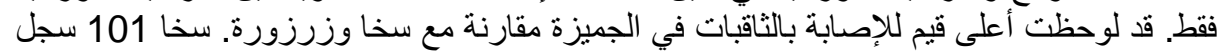

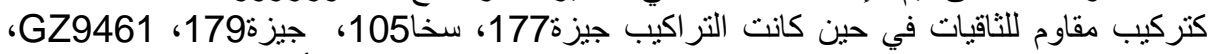

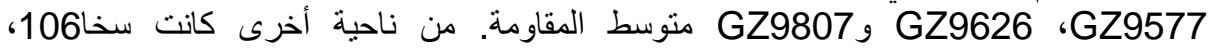
GZ9523، GZ7576 متوسطة الإصابة. كان جيزة GZ78

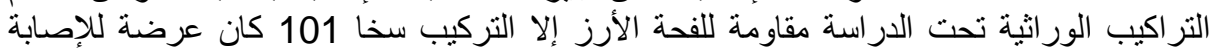
تحت المو اقع المختلفة في العامين. 